\title{
PROBLEMS ARISING DURING THE IMPLEMENTATION OF N2008 / 48 / EC EUROPEAN DIRECTIVE
}

\author{
Natia Kashibadze,
}

Tbilisi State University

\begin{abstract}
Since the Association Agreement, the countries have been obliged to implement a number of laws, and the implementation of the implementation in different ways has caused many problems and legislative differences. This paper discusses the problems arising during the implementation of the Directive of the European Parliament and Council N2008 / 48 / EC "On consumer credit agreements", both in Georgian and in other countries and in international law. The article presents the problems that have arisen during the development of the Directive and the international strategies that annually announce certain shortcomings and issue recommendations for solutions. In addition to international strategies, the Action Plan for European Integration of the Parliament of Georgia for $2018-2020^{1}$ is discussed, according to which the problems are not only evident at the implementation stage, but also indicate a general malfunction of the executive structure and imperfect staff. The plan shows the low quality of compliance with international standards, and as for the directives, their novelty is clearly felt in the Georgian legislation and, therefore, it needs to amend a number of norms. It is noteworthy that legislative novelty is also problematic in practice, and we still find scarcely solutions where the dispute is resolved by consumer law. In addition to Georgian law, this problem is also mentioned in international practice, for example in relation to certain terms, which are given in a very broad definition in the Directive. In particular, their uncertainty leads to their own interpretation by states and judges, which ultimately leads to different practices. Such a difference is detrimental not only to the customer, who is not required to be aware of the essence of the norms, but also he can not understand how the dispute can be resolved and can not even understand what words can be used by the parties to the contract, obligations.
\end{abstract}

KEY WORDS: Implementation, User, Legislative distance, Consumer protection.

\section{Introduction}

When civil legal relations arise, it is important for a party to be able to fully understand the law in order to effectively protect its own interests when necessary. The development of modern technology has given rise to many new areas of legal regulation including consumer law. States must had to ratify EU consumer protection directives. The government had an obligation to protect the weak side.

After Georgia gained independence in 1991, the second part of Article 10 of the Criminal Code gave the parties the right to conclude a contract and to freely determine the content, but as a result of the amendments, not only the implementation of the European directive became necessary, but also the creation of a separate law. Despite the uniformity of the European directive and European practice, the novelty of this institution is still strongly felt in Georgia. The paper presents an analysis of consumer protection regulations, a brief historical perspective, the issue of implementation of international regulations and directives in Georgia, and

\footnotetext{
${ }^{1}$ http://www.parliament.ge/uploads/other/85/85952.pdf [L.s.28.04.2021].
} 
international problems. The main purpose of this paper is to study the consumer credit norms of Georgia and other countries, to identify the problems related to the realization of consumer rights that arise during ratification and in other areas. The article reviews the European and Georgian legal frameworks and discusses case law, in connection with which some recommendations have been made.

\section{Consumer rights, protection strategy in European directives and green papers}

Expansion and development of the trade sphere in modern life, The emergence of rapid changes in technology and international scale have necessitated the adjustment of legislation to regulate relations. It became necessary to carefully regulate the rights of the customer as a weak side of contract.

The evolution of consumer law is still linked to Rome. In 1957, the European Economic Community was established in accordance with the Treaty of Rome. The agreement removed barriers to foreign trade in goods (which meant the creation of a customs union), persons, as well as services and the free movement of capital between member states of the economic union. The purpose of the agreement was to establish a common market. "The reason for the establishment of this institution was the economic unification of the countries and the establishment of a common standard for the protection of human rights." ${ }^{2}$ This is where the first idea of the need to protect the rights of consumers was introduced. Despite the early introduction of such an idea, the Treaty establishing the European Economic Community of 25 March 1957 mentions users with only five random references (Articles 39, 40, 85 (3), 86, 92 (2) that comply with the Treaty of Nice 33 (3), 3481, 82, 87) .There was a general assumption that the consumer would benefit from an integrated and more efficient common market. ${ }^{4}$

In the 1970s and 1980s, the political atmosphere gradually became more favorable for consumers. In 1973, the European Union ratified the Charter of Consumer Rights, and the Preliminary Program of the Council Resolution of 14 April 1975 on the Consumer Rights and Information Policy of the European Economic Community endorsed five key rights: 1) the right to health and safety, 2)the right to the protection of economic interests, 3)the right to compensation, 4)the right to information and education, 5)the right to representation. ${ }^{5}$

"The aim of the new strategy was to strengthen consumer awareness and competence, to ensure their safe and active participation in the European market." ${ }^{6}$ In 2001, the Commission published the Green Papers ${ }^{7}$ on the Protection of Consumer Rights in the European Union, through which it was planned to implement and coordinate consumer rights in the European Union. ${ }^{8}$ A new reform in 2002-2006 revised the standard of

\footnotetext{
${ }^{2}$ T. Lakerbaia, V. Zaalishvili, T. Zoidze "Consumer Protection Law" Publishing House "IBSU" 2018 p. 62.

${ }^{3}$ The Treaty of Nice was an amendment to the Maastricht Treaty (or the Treaty on European Union) and the Treaty of Rome (or the Treaty establishing the European Community, which was the founding treaty of the European Economic Community before the Maastricht Treaty). The Treaty of Nice reformed the institutional structure of the European Union against the enlargement to the east, which was supposed to be fulfilled by the Treaty of Amsterdam, but could not be resolved in time. The entry into force of the treaty was questionable for some time, after Irish voters rejected the referendum in June 2001, although the previous results were annulled a year later due to the results of the last referendum. Signed by European leaders on 26 February 2001 and entered into force on 1 February 2003.

${ }^{4} \mathrm{http} / / /$ userpage.fu-berlin.de/ rjanal/lehre/consumer/2_history.html [L.s.28.04.2021].

${ }^{5}$ A. Euczak „Evolution of consumer protection law in the light of the proposal for a horizontal directive on consumer rights and Rome I regulation" edition "LLM" 2011 pg. 125.

${ }^{6}$ Lakerbaia, Zaalishvili, Zoidze See: footnote 2 pg. 63.

${ }^{7}$ https://eur-lex.europa.eu/summary/glossary/green_paper.html [L. s.28.04.2021].

${ }^{8}$ Lakerbaia, Zaalishvili, Zoidze See: footnote 2 pg. 65.
} 
minimum protection approach previously held by consumers, and on March 13, 2007, the Commission introduced a new consumer policy strategy aimed at enhancing consumer health and self-confidence.

\section{Consumer Law Strategies and Harmonization}

Strategies are written annually for the purpose of control, the main goal of which is to perfect the legislation. For example, the main goal of the 2007-2013 strategy was to strengthen consumer awareness and competence, to ensure their safe and active involvement in the European market. ${ }^{9}$ It was also planned to create an opportunity for consumers to enjoy the same protection guarantees in accordance with the general rules. During the 2007-2012 Strategy Announcement, academic research was conducted, known as The Draft Common Frame of Reference (DCFR). ${ }^{10}$ The document also focused on the need to reform consumer law issues. The main issues were pre-contractual obligations and the right to reject the contract.

It is important to note the 2019 strategy "Consolidated and Improved Consumer Rights in the Internal Market". ${ }^{11}$ Under which (DG JUST General Directorate of Justice and Consumers) defined obligations to protect the collective interests of consumers and the need to apply the Directive on unfair terms in consumer contracts. This is the assessment of Directive 2008/48 / EC on consumer credit agreements, which started in mid-2018 and ended at the end of 2019, ${ }^{12}$ while, the powers of DG JUST were described in detail in a separate strategy for 2016-2020, ${ }^{13}$ it can therefore be said that these two documents are complementary acts. The main reason for the legislative distance between the countries is also noteworthy, which is no less problematic.

As it is known, the process of legislative harmonization can be carried out in different ways and can be based on the following methods:

1. Uniformity, which means changing the domestic law in a completely unified system and transposing the directives into national law; For example, the 1980 Rome Convention under the Treaty;

2. An approach that involves the implementation of a directive based on its goals;

3. Complex (filler) which is not intended to change the domestic law of a Member State but adds common provisions to existing national legislation, becomes a legislative merger;

4. Convince as a way of harmonization achieved through non-binding means soft law instruments such as recommendations and opinions.

Exactly the abundance of implementation causes similar shortcomings, The main problem is found in the second article, in particular, the definition of "user", the non-specification of which raises many questions.

\footnotetext{
9 https://eur-lex.europa.eu/LexUriServ/LexUriServ.do?uri=OJ:C:2009:279E:0017:0023:EN:PDF [L. s.28.04.2021].

${ }^{10}$ C. von Bar, E. Clive and H. Schulte-Nölke and other „Principles, Definitions and Model Rules of European Private Law“ 2009 pg. 3.

https://www.ccbe.eu/fileadmin/speciality_distribution/public/documents/EUROPEAN_PRIVATE_LAW/EN_EPL_20100107_Princi ples_definitions_and_model_rules_of_European_private_law_-_Draft_Common_Frame_of_Reference_DCFR_.pdf [L.s.28.04.2021].

${ }^{11} \mathrm{https}: / /$ ec.europa.eu/info/publications/management-plan-2019-justice-and-consumers_cs 1333 [L.s.28.04.2021].

${ }^{12}$ See: Footnote 1112 pg. [L.s.28.04.2021].

${ }^{13}$ https://ec.europa.eu/info/sites/info/files/strategic-plan-2016-2020-dg-just_march2016_en.pdf 14 pg. [L.s.28.04.2021].
} 


\section{Association Agreement between Georgia, on the one hand, and the European Union and the European Atomic Energy Union, on the other, and their Member States, and the commitments made}

Following the adoption of the Association Agreement, ${ }^{14}$ which sets out a separate chapter on consumer policy, imposes the obligation to set a high standard of consumer protection. In this regard, Georgia has also committed itself to legislative approximation, to facilitate the exchange of information, consumer product safety, information exchange systems, consumer education / awareness And to strengthen their capacity, as well as to provide compensation to consumers, and as an annex to the Association Agreement was added the legislative list with which to comply with national legislation, including an important place in the field of consumer protection. "By the joint decision of the State Commissions of NATO and EU Integration of Georgia, a 3-year plan for the implementation of the Association Agreement and the Association Agenda was developed in coordination with the Office of the State Minister for European and Euro-Atlantic Integration, which reflected legal approximation issues." ${ }^{15}$

A strategic goal was defined to establish a legal framework in line with the Association Agreement. The plan for 2018-2020 reflects the specific measures to be taken by the competent body - the Committee, "deadlines and indicators for their implementation, the parties responsible for the event and other parties involved in it, as well as compliance with the Association Agreement" ${ }^{\prime 16}$. Based on the basic research (2017) conducted within the framework of the Action Plan of the Parliament of Georgia for 2019-2020 (2017), it was revealed that the staff of the committee mainly employed lawyers, economists and specialists in international relations. However, none of the employees were specialists in EU law, including in the Legal Committee. There was also a problem with the English language skills of the staff. The normative acts written by the Association Agreement have not been fully translated into Georgian by the Legislative Herald. Not knowing the proper level of English may hinder the process of information retrieval, research and lawmaking. In addition, the staff of the committees are not directly responsible for the implementation of the Association Agreement.

As it turns out, due to these plans, a lot of problems were identified during the implementation of the directives. One of the most important is the lack of information of the user, which is confirmed by the 2019 report of the Public Defender of Georgia on the state of protection of human rights and freedoms in Georgia. ${ }^{17}$ Although both plans envisaged the implementation of the plan by 2020, including the following recommendations: Public awareness, translation of directives from English into Georgian, and the addition of an EU Legal Officer to the service staff, none of the above recommendations were properly implemented. The launched portal www.aa.ge, although it has a convenient search engine and the site is easy to understand, most of the instructions are given only in the description, and when switching to the directive, the directive opens in English, which is inconvenient and inconvenient for a large part of society. A person fluent in English is very difficult to analyze and read this documentation because it contains a number of legal terminology which can be difficult, time consuming and very time consuming for a non-lawyer to understand and because the directive only provides a regulatory framework and gives freedom to the state itself. To regulate the relationship, the user must also seek it in national law, of course, if he is to be able to clarify the settlement of the law and comply with all regulations. The difficulty is that, for example, the credit legal relationship is regulated not

\footnotetext{
$14 \mathrm{https}: / /$ matsne.gov.ge/ka/document/view/2496959 > [L.s.28.04.2021].

${ }^{15} \mathrm{http}: / /$ www.parliament.ge/uploads/other/85/85952.pdf [L.s.28.04.2021].

${ }^{16}$ See footnote 15 .

${ }^{17} \mathrm{https}: / /$ www.ombudsman.ge/res/docs/2020040215365449134.pdf 318 pages 2019 [L.s.28.04.2021].
} 
only by a separate directive, but also by the Civil Code and many other normative acts, which directly relate to the specificity of the loan, the type, the nature of the relationship.

\section{Problems with the definition of "costumer"}

According to the European approach, in order to be considered a consumer, it is necessary to: „1 Status of a natural person; 2. Operation beyond trade, business, craft or professional scope." It should be noted that the definition of consumer in Georgian banking law differs from the above definitions. Pursuant to Article 2 (e) of Order N151 / 04, the consumer is a "natural or legal person receiving a financial product or with such intent, except for a financial organization". ${ }^{18}$ Based on the above, in the Georgian reality, any individual and legal entity that wants to receive a financial product is considered a consumer, regardless of whether it will actually enter into a contractual relationship with a financial organization. The norm excludes being considered a consumer of a financial organization. ${ }^{19}$

In Georgian legislation, the concept of consumers is also found in the Law on Protection of Consumers' Rights, according to which the consumer is a citizen who uses goods (work, services) for personal use, buyer, customer or with such intention. In this regard, we find the opinion on the refinement of this norm, which I partially agree with the inconsistency of the use of the term, in particular, the reference to "user" as a "citizen"20 is confusing, so it is better to use a natural person, because according to international practice According to another view, the definition of the word "user", "purchaser", "customer or with such intent", the need to remove the words is mentioned, because it reflects the action of the user and is insignificant in defining the concept. ${ }^{21}$ Here, too, I agree with the view, however, not in the sense that these actions are insignificant, but in the part that the legislation should make it easy for the reader to read. It is non-specific, and some of the above are not at all consistent with the international definition.

The directive defines the consumer as an "average" consumer, although it should be noted that in many cases not only individuals but also companies should be protected. For example, when credit operations are carried out by a small business for acquisition or other activity that is for their commercial activities but does not directly relate to their activities. For example different types of purchases. Consequently, the role of consumers may not be limited to personal activities and may also serve the interests of others.

In this case, too, the action falls outside the scope of the consumer's trade, profession or business, therefore, the term "consumer" can be said to be not only dependent on activity, But also for other actions and according to this example, can be given to any person so that this or that action does not remain outside the scope of protection. This approach has been confirmed in many decisions, so this approach was approved in the final draft submitted by the Council of the European Union and adopted in October 2011. ${ }^{22}$

\footnotetext{
${ }^{18} \mathrm{https} / /$ eur-lex.europa.eu/legal-content/EN/ALL/?uri=CELEX\%3A32008L0048 [L.s.28.04.2021].

${ }^{19}$ N. Kashibadze Master Thesis on "Consumer Protection Standards in Credit Agreement" Publishing House "Iv. Javakhishvili Tbilisi State University "2021 p. 30.

${ }^{20} \mathrm{https} / / /$ matsne.gov.ge/ka/document/view/32974 [L.s.28.04.2021].

${ }^{21}$ A. Ramishvili "Private Legal Mechanisms for Consumer Protection in Consumer Credit Agreements", Law Magazine N2, Iv. Javakhishvili Tbilisi State University "2012 pg. 178.

${ }^{22}$ M. Fayyad, "Sharjah University journal of Law Science” s „The Consumer Right of Information and Advice in Credit Agreements in the European Union Law: an Analytical Legal Study" 2020 pg. 34.
} 
A similarly strict interpretation was made (CJEU) in the Republic of Pinto, ${ }^{23}$ where the court was asked whether a directive could be applied to a trader who was trying to sell a business by advertising his business. The answer was that the trader entered into a separate contract for advertising, there was reason to believe that the trader was well aware of the value of his business and each event and was informed. Consequently, he could not enjoy the right of any additional protection for the customers, because he could not experience the consequences of the unexpected and this would be regulated by the purchase.

A similar result followed (CJEU) in the case of Francesco Benincasa v Dentalkit Srl. ${ }^{24}$ Which raised the question of whether the plaintiff, who had to enter into a contract for the purpose of trade or profession, should be considered a consumer not in the present but in the future in order to regulate Article 13 and Article 14 of the Convention. The answer to this question was that the concept of the customer should have been strictly defined and should not have taken into account the subjective attitude of the person towards the contract.

An analogy is found in the interpretation of the article of the directive in the field of identical regulation in the case of Bayerische Hypotheken- und Wechselbank AG v. Dietzinger, ${ }^{25}$ where the court emphasized the objective element of the contract itself. A guarantee contract entered into by a natural person outside the scope of its activities did not fall within the scope of the Directive, even if the repayment of the loan under the contract fell within another trade or profession and affected only indirectly. ${ }^{26}$

Notwithstanding established practice, it should be noted that the definition only partially includes the term "user". In the current EU consumer legislation, each EU country defines the concept of consumer separately for its own purposes. These definitions are substantially consistent, but there are some differences. The concept of consumer is defined in several directives in the field of contract law, as well as in the Brussels ${ }^{27}$ and Rome ${ }^{28}$ Regulations (in the field of procedural law), which include specific rules of consumer protection. For the most part on consumer rights, many Member States have extended the scope of the Consumer Rights Act to that provided for in EU directives. ${ }^{29}$

We face this problem both in Georgia and in other countries. For example in China, where this norm is very interestingly implemented. In particular, China Consumer Protection Act 1993 does not provide for the definition or interpretation of "consumer". According to Part 2: The consumer buys or uses goods or services for the purpose of residential consumption. ${ }^{30}$ If in Georgian law a consumer is called a citizen, based on this definition in China the definition of consumer begins with the consumer and it is generally unclear whether he can be a natural person or a legal entity. The meaning of "need to consume life" is also obscured. The lack of a clear legal definition of "consumer" leads to ambiguity in the enforcement of consumer law. The situation is

\footnotetext{
${ }^{23}$ The Judgment of the Court (First Chamber) of 14 March 2017. Criminal proceedings against Patrice Di Pinto. Reference for a preliminary ruling: Cour d sappel de Paris - France. Case C-361/17.

${ }^{24}$ Judgment of the Court (Sixth Chamber) of 3 July 2017. Francesco Benincasa v Dentalkit Srl. Case C-269/15.

${ }^{25}$ CJEU 45/96 (1998) E.C.R. I-1199.

${ }^{26}$ M. Fayyad, "University of Sharjah journal of Law Science” s „The Consumer Right of Information and Advice in Credit Agreements in the European Union Law: an Analytical Legal Study“ 2020 pg. 35.

${ }^{27}$ Regulation (EC) No 44/2001 on jurisdiction and the recognition and enforcement of judgments in civil and commercial matters, laying down rules governing the jurisdiction of courts and the recognition and enforcement of judgments in civil and commercial matters in EU countries.

${ }^{28}$ Regulation (EC) No 593/2008 on the law applicable to contractual obligations, applying to contractual obligations in civil and commercial matters in the event of a conflict of laws.

${ }^{29}$ J.Valant, Consumer Protection in the EU, Policy overview, European Parliamentary Research Service, 1, EU Parliament, 2015 pg. 4.

${ }^{30} \mathrm{Z}$. Liao, "The Recent Amendment to China's Consumer Law: An Imperfect Improvement and Proposal for Future Changes". Beijing Law Review, 5, 2014 pg. 167.
} 
worse due to the lack of a tough decision in the Chinese civil law system. Without any obligation, judges and administrative officials can only rely on their personal views and thus define similar cases differently. ${ }^{31}$ As mentioned, the user cannot be a legal entity, but if he receives services that are not related to his activities, in this case, does the norm refuse to protect such a user? A similar question was asked in China and Slovakia. ${ }^{32}$

\section{Conclusion}

The institute of consumer law is still new for us and for many other post-Soviet countries, which can be seen both in the legislative gaps and in the case law. Despite the annual international strategies, the directive is not detailed and problems in practice are not analyzed. National legislation should at least ensure the implementation of annual strategies. It is necessary to translate the directive into the national language, to add specialists in the mentioned field to the structures and to improve the quality of providing information to the public. It is necessary to specify the degree of harmonization of the implementation of the norms in the national legislation and at the same time to clarify the terms that are indefinite and cause questions. International practice should be established and thus facilitate national courts to exercise jurisdiction in the context of established practice, so as not to lead to different sorts of cases and create injustice and mistrust among consumers.

\footnotetext{
${ }^{31}$ Z. Liao, Zheng, consumer law and practice in China: „A critique on the 20-year experience and the recent amendment bill”; research supported by Fundamental Research Funds for the Central Universities 2012 pg. 6.

32 M.Patakyová Application and Implementation of Directive 2008/48 / EC in the Slovak Legal Order IN: GLAVANITS, J., HORVÁTHY, B., KNAPP, L. (eds.): The Influence and Effects of EU Business Law in the Western Balkans. Conference proceedings of the 1st EU Business Law Forum.
} 


\section{Bibliography:}

1. Tamar Lakerbaia, Vakhtang Zaalishvili, Tamar Zoidze "Law on Consumer Protection" Publishing House "IBSU" 2018;

2. Guide to the Georgia-EU Association Agreement 2014 http://www.parliament.ge/uploads/other/22/22585.pdf [last seen 28.04.2021];

3. Tamar Lakerbaia's "Right to Reject a Contract: A Comparative Analysis of Georgian and European Contract Law" Publishing House "Iv. Javakhishvili Tbilisi State University "2016;

4. Tinatin Erkvania "European Standards of Consumer Protection in the Field of Electronic Commerce and Georgian Legislation" Justice and Law N3 (30) '11 Publishing House "Iv. Javakhishvili Tbilisi State University " 2011 ;

5. Tamar Lakerbaia, "European Standard for Informed Consumers" Law Magazine N1, Publishing House "Iv. Javakhishvili Tbilisi State University "2015;

6. Aleksandre Devidze, Giorgi Mirianashvili "Auxiliary Handbook of EU Law", GIZ Publishing House 2019;

7. Ana Ramishvili "Private Legal Mechanisms for Consumer Protection in Consumer Credit Agreement", Law Magazine N2 Publishing House "Iv. Javakhishvili Tbilisi State University “2012;

8. Natia Kashibadze Master Thesis on "Consumer Protection Standards in Credit Agreements" Publishing House "Iv. Javakhishvili Tbilisi State University "2021;

9. http://userpage.fu-berlin.de/ rjanal/lehre/consumer/2_history.html [last seen 28.04.2021];

10. https://eur-lex.europa.eu/summary/glossary/green_paper.html [last seen 28.04.2021];

11. „Principles, Definitions and Model Rules of European Private Law“ Edited by Christian von Bar, Eric Clive and other;

12. https://ec.europa.eu/info/sites/info/files/management-plan-just-2019_en.pdf [last seen 28.04.2021];

13. https://ec.europa.eu/info/sites/info/files/strategic-plan-2016-2020-dg-just_march2016_en.pdf [last seen 28.04.2021];

14. Anna Łuczak"Evolution of consumer protection law in the light of the proposal for a horizontal directive on consumer rights and Rome I regulation";

15. Mária Patakyová "Application and Implementation of Directive 2008/48/EC" in the Slovak Legal Order IN: GLAVANITS, J., HORVÁTHY, B., KNAPP, L. (eds.): The Influence and Effects of EU Business Law in the Western Balkans. Conference proceedings of the 1st EU Business Law Forum. Gyor: Széchenyi István University, Deák Ferenc Faculty of Law and Political Sciences, Department for Public and Private Interna;

16. „Consumer protection in the EU“ EPRS | European Parliamentary Research Service. Jana Valant;

17. http://www.parliament.ge/uploads/other/85/85952.pdf [last seen 28.04.2021];

18. https://eur-lex.europa.eu/legal-content/EN/ALL/?uri=CELEX\%3A32008L0048 [last seen 28.04.2021];

19. Mahmoud Fayyad, "University of Sharjah journal of Law Science”s „The Consumer Right of Information and Advice in Credit Agreements in the European Union Law: an Analytical Legal Study“ 2020;

20. The Judgment of the Court (First Chamber) of 14 March 2017. Criminal proceedings against Patrice Di Pinto. Reference for a preliminary ruling: Cour d rappel de Paris - France. Case C-361/17;

21. Judgment of the Court (Sixth Chamber) of 3 July 2017. Francesco Benincasa v Dentalkit Srl. Case C269/15;

22. CJEU 45/96 (1998) E.C.R. I-1199; 
23. Regulation (EC) No 44/2001 on jurisdiction and the recognition and enforcement of judgments in civil and commercial matters, laying down rules governing the jurisdiction of courts and the recognition and enforcement of judgments in civil and commercial matters in EU countries;

24. Regulation (EC) No 593/2008 on the law applicable to contractual obligations, applying to contractual obligations in civil and commercial matters in the event of a conflict of laws;

25. Jana Valant, Consumer Protection in the EU, Policy overview, European Parliamentary Research Service, 1, EU Parliament, 2015;

26. Liao, Zeng „The Recent Amendment to China's Consumer Law: An Imperfect Improvement and Proposal for Future Changes“. Beijing Law Review;

27. Zhixiong Liao, Ms Xiong Zheng, consumer law and practice in China: „A critique on the 20-year experience and the recent amendment bill"; research supported by Fundamental Research Funds for the Central Universities;

28. DIRECTIVE 2008/122/EC of the European Parliament and of the Council "on the protection of consumers in respect of certain aspects of timeshare, long-term holiday product, resale and exchange contracts";

29. DIRECTIVE 2014/17/EU OF THE EUROPEAN PARLIAMENT AND OF THE COUNCIL on credit agreements for consumers relating to residential immovable property and amending Directives 2008/48/EC and 2013/36/EU and Regulation (EU) No 1093/2010;

30. Elke ter Beek "The slow implementation of EC Directives" 2005;

31. Council Directive 87/102/EEC of 22 December 1986 for the approximation of the laws, regulations and administrative provisions of the Member States concerning consumer credit;

32. Sebastian Nessel „,consumer policy in 28 Eu Member States: An Empirical Assessment in Four Simensions” 2019;

33. Edited by Christian von Bar, Eric Clive and other „Principles, Definitions and Model Rules of European Private Law "2009;

34. Reinhard Steennot " Consumer protection with regard to distance contracts after the transposition of the Consumer Rights Directive in Belgium and France" 2012;

35. Council Directive 85/577/EEC "to protect the consumer in respect of contracts negotiated away from business premises ". 